\title{
ASSESSMENT OF HEAVY METAL AND TOXIC ELEMENT CONTENT IN BARLEY (HORDEUM VULGARE L.) AND SOIL
}

\author{
BENGISU, G. \\ Department of Field Crops, Faculty of Agriculture, Harran University, Şanluurfa-Mardin \\ Karayolu Üzeri 18.Km, Harran, Sanliurfa, Turkey \\ (e-mail: gbengisu@hotmail.com; phone: +90-414-318-3000; fax: +90-414-318-3190)
}

(Received 13 $3^{\text {th }}$ Mar 2019; accepted 13 $3^{\text {th }}$ Jun 2019)

\begin{abstract}
One of the largest problems threatening human and animal health is environmental pollution, which has increased in parallel with industrialization and population growth. Because of environmental pollution, pollution in agricultural soils and plant products has approached dangerous levels. Barley, which is commonly used in animal nutrition and the food industry, is one of the plants that is affected by such pollution. In these plants, it is very important to determine the level of pollution present for the sake of both human and animal health. In accordance with this purpose, we measured the levels of $\mathrm{Cd}, \mathrm{Cu}, \mathrm{Fe}$, $\mathrm{Mn}, \mathrm{Ni}, \mathrm{Pb}$, and $\mathrm{Znin}$ barley plants and soil samples collected from three locations in Southeastern Anatolia, where barley production is common in Turkey. Results show that the concentrations of mineral elements except $\mathrm{Fe}$ in the soil samples are below critical limits. Instead of high Fe concentration in soils, all mineral elements in plant samples collected from all locations are below critical limits. The concentrations measured in soil and barley samples from the Kiziltepe location were the lowest.
\end{abstract}

Keywords: barley, cadmium, copper, iron, manganese, nickel, lead, zinc

\section{Introduction}

Irregular urbanization, the proximity of agricultural land to city centers, increased household and industrial wastes, heavy metals emitted from chimneys and exhaust fumes cause heavy metal accumulation in plants and, subsequently, changes in their physiological and genetic structures. While heavy metals such as copper $(\mathrm{Cu})$, zinc $(\mathrm{Zn})$, cobalt $(\mathrm{Co})$, manganese $(\mathrm{Mn})$, nickel $(\mathrm{Ni})$ and molybdenum (Mo) are absolutely necessary for plant growth, lead $(\mathrm{Pb})$, vanadium $(\mathrm{V})$, aluminum $(\mathrm{Al})$, arsenic (As), mercury $(\mathrm{Hg})$, cadmium $(\mathrm{Cd})$ and selenium $(\mathrm{Se})$ have toxic effects. If the heavy metal content in plants is above the prescribed limit, serious health problems can develop in the humans and other animals that eat these plants (Okturen and Sonmez, 2006; Caglairmak and Hepcimen, 2010; Nagajyoti et al., 2010).

For example, cadmium has toxic effects on all organ systems in animals. In cases of cadmium poisoning, a decrease in feed consumption, reduced growth, infertility, a decreased number of pups, liver and kidney damage, anemia and death are observed (Bernhoft, 2013). In cattle with acute copper poisoning, gastrointestinal inflammation, swelling, diarrhea and the rapid loss of fluid-electrolyte are observed, and in other animals, loss of appetite and severe depression are observed. If acute poisoning is not treated, death may occur within three days (Scott et al., 2011). The most common effects of the Nickel poisoning are lung cancer, kidney edema, allergic reactions, a decreased number of sperm and sperm abnormalities (Kawanishi et al., 2001). Nausea, vomiting, epigastric pain, lethargy, and fatigue occur with extremely high levels of zinc intake (Fosmire, 1990). Manganese toxicity tends to lead to neurological symptoms, including headaches, muscle cramps, fatigue and aggressiveness (Aschner et al., 2009). Excess lead accumulates in the bones and destroys the kidney, brain and nervous system (Kahvecioglu et al., 2004). Excessive amounts of iron can damage to various organs and 
systems, especially the liver, pancreas and other endocrine organs, as well as the heart (Aydin, 2008).

Barley (Hordeum vulgare L.), which we have investigated in this study, is widely used in human nutrition and animal feeding. Barley is used as feed crop and the beer industry's main raw material in Turkey, and it is the second most produced cereal, with wheat being the first. Heavy metals are difficult to remove from the environment. They also cannot be chemically or biologically degraded (Chaney et al., 1997). Barley is among the best performing grass species in terms of extracting some toxic metals from the soil (Ebbs and Kochian, 1998).

In this study, we aimed to measure mineral element content $(\mathrm{Cd}, \mathrm{Cu}, \mathrm{Fe}, \mathrm{Mn}, \mathrm{Ni}, \mathrm{Pb}$ and $\mathrm{Zn}$ ) in barley plants and soil collected from various locations.

\section{Material and methods}

\section{Sampling}

The study was carried out in the Southeastern Anatolia region of Turkey in 2016. A total of thirty barley and soil samples were collected from three locations in this region from the Çınar District of Diyarbakir (Latitude: $37^{\circ} 43^{\prime} 27^{\prime \prime} \mathrm{N}$, Longitude: $40^{\circ} 24^{\prime} 54^{\prime \prime}$ E), the Siverek District of Şanlıurfa (Latitude: $37^{\circ} 45^{\prime} 7^{\prime \prime}$ N, Longitude: $39^{\circ} 19^{\prime} 55^{\prime \prime} \mathrm{E}$ ), and the Kizıltepe District of Mardin (Latitude: $37^{\circ} 11^{\prime} 23^{\prime \prime} \mathrm{N}$ Longitude: $40^{\circ} 34^{\prime} 47^{\prime \prime} \mathrm{E}$ ) (Fig. 1).

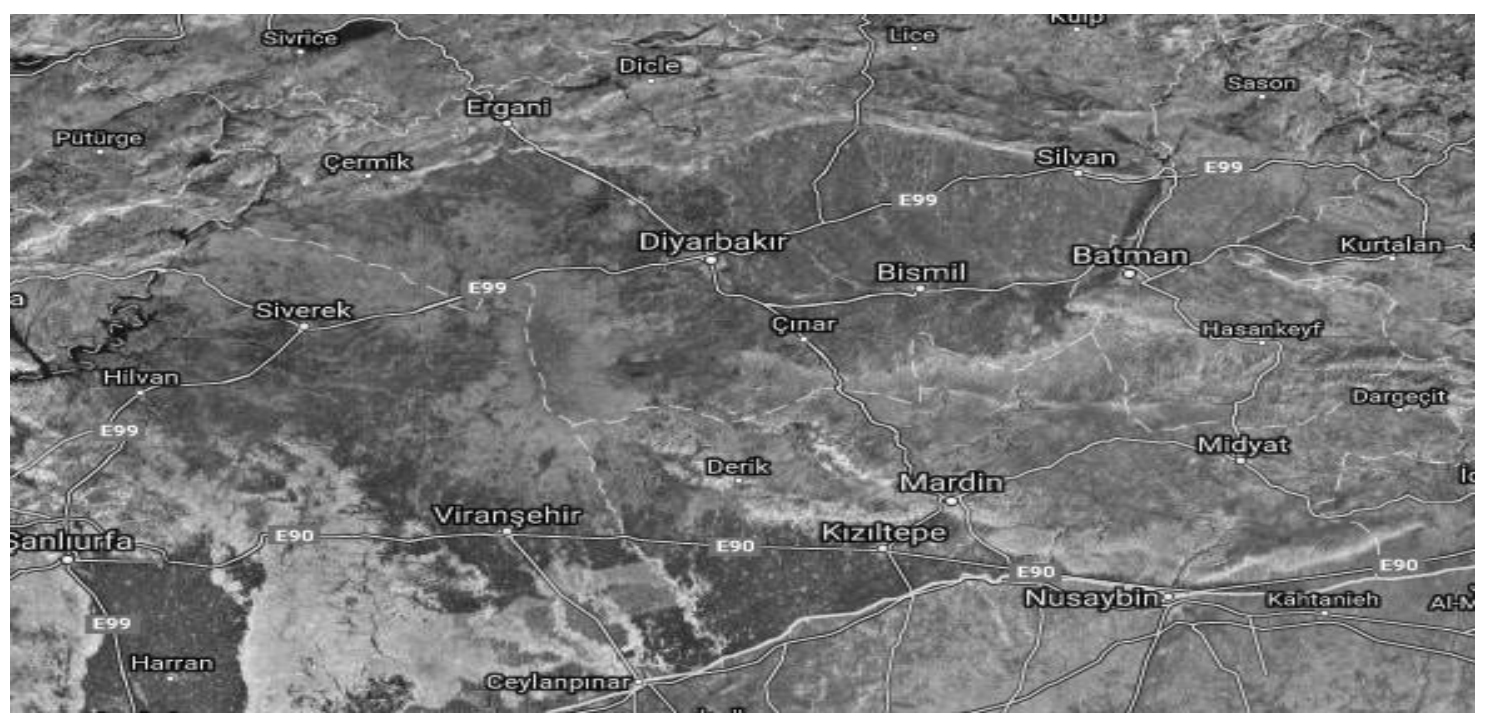

Figure 1. Sampling locations (Çinar, Kiziltepe and Siverek)

When the data for the soil and barley specimens were analyzed, ten samples from each station were analyzed separately, and the arithmetic average of the values obtained was found. All barley samples were commercially available. In order to preserve the original quality of the barley, the samples were stored at an ambient temperature in sealed plastic bags prior to any conditioning. Distilled water was further purified with a Milli-Q ${ }^{\mathrm{TM}}$ system (Millipore Corporation, USA) and used throughout the experiments. The hydrogen peroxide $\left(\mathrm{H}_{2} \mathrm{O}_{2}, 30 \%\right)$ and nitric acid (HNO3, 65\%) used for the digestion were of analytical grade (E. Merck, Darmstadt, Germany). 


\section{Digestion procedure}

A Berghof MWS-3 model microwave digestion system (Berghof, USA) was used for the digestion of the barley samples. Microwave (MW) digestion was carried out as follows: half-gram barley samples and a solid reference material were weighed and transferred into pressure-resistant PTFE vessels, and $9.0 \mathrm{~mL}$ of the acid mixture $\left(\mathrm{HNO}_{3}-\mathrm{H}_{2} \mathrm{O}_{2}, 2: 1\right)$ was added to each sample. The vessels were closed, and a total of six samples were evenly spaced on the microwave oven carousel. The program of the MW digestion is provided below (Table 1).

Table 1. Operating conditions for two-stage digestion by microwave oven (Tuzun and Yakut, 2009)

\begin{tabular}{c|c|c|c|c|c|c}
\hline Step 1 & $\mathbf{1}$ & $\mathbf{2}$ & $\mathbf{3}$ & Step 2 & $\mathbf{1}$ & $\mathbf{2}$ \\
\hline $\mathrm{T}(0 \mathrm{C})$ & 140 & 160 & 190 & $\mathrm{~T}(0 \mathrm{C})$ & 160 & 100 \\
$\mathrm{Ta}[\mathrm{min}] \mathrm{a}$ & 5 & 3 & 5 & Ta $[\mathrm{min}] \mathrm{a}$ & 3 & 1 \\
Time $[\mathrm{min}] \mathrm{b}$ & 5 & 10 & 20 & Time $[\mathrm{min}] \mathrm{b}$ & 15 & 15 \\
\hline
\end{tabular}

The power applied was $800 \mathrm{~W}$. After the digestion procedure, the reaction mixture was evaporated in order to remove the acids. Then, the residue was dissolved in approximately $25 \mathrm{~mL}$ of Milli-Q ${ }^{\mathrm{TM}}$ water (Millipore Corporation, USA). Then, ICPOES measurements of $\mathrm{Cd}, \mathrm{Cu}, \mathrm{Fe}, \mathrm{Mn}, \mathrm{Ni}, \mathrm{Pband} \mathrm{Zn}$ were performed for the diluted solutions (Celik et al., 2014).

\section{Instrumentation}

An Optima 2100 DV (dual view) inductively coupled plasma optical emission spectrometer (Perkin Elmer, Inc., Shelton, CT, USA) was used for the determination of $\mathrm{Cu}, \mathrm{Fe}, \mathrm{Mn}, \mathrm{Ni}, \mathrm{Pb}$ and $\mathrm{Zn}$ in the barley and soil in the diluted solutions. The instrumental operating parameters are listed in Table 2. All of the procedures, from sampling to analysis, were also applied to blanks in order to evaluate any metal contamination during the analytical procedure. A blank was simultaneously prepared, and all procedures were applied before the measurements. The selection of the instrumental parameters and optical wavelengths was based on obtaining good sensitivity, ensuring reasonable detection limits and eliminating interferences (Duz et al., 2012). All samples were digested and analyzed in triplicate. The analytical wavelengths and average detection limits calculated for all measurements are listed below (Table 2).

\section{Analytical procedure}

The limits of detection (LOD) and limits of quantification (LOQ) for each metal were determined as follows: ten independent analyses of a blank solution spiked with the metal at a lower level concentration on the analytical curve were performed. The LOD and LOQ were calculated using the standard deviation $(\sigma)$ of these determinations $(\mathrm{LOD}=3 \times \sigma$, and $\mathrm{LOQ}=10 \times \sigma)$ (Bora et al., 2015). The analytical wavelengths and average detection limits calculated for all measurements, as well as the minimum, maximum and average concentrations of the elements in the samples, are listed below (Table 3). 
Table 2. Operating conditions of the ICP-OES (Perkin Elmer Optima 2100 DV)

\begin{tabular}{c|c}
\hline Parameter & \\
\hline RF power (W) & 1450 \\
Plasma gas flow rate (L min-1) & 15 \\
Auxiliary gas flow rate (L min-1) & 0.2 \\
Nebulizer gas flow rate (L min-1) & 0.8 \\
Sample flow rate (L min-1) & 1.5 \\
View mode & Axial \\
Read & Peak Area \\
Source equilibration time (s) & 15 \\
Read delay (s) & 30 \\
Replicates & 3 \\
Background correction & 2-point (manual correction) \\
Spray chamber & Scott type \\
Nebuliser & Cross-Flow GemTip \\
Detector & CCD \\
Purge gas & Nitrogen \\
Shear gas & Air \\
Gas & Agron \\
Wavelength (nm) & Ni: 231.604, Se: 196.090
\end{tabular}

Table 3. Linear range, regression, correlation coefficient $(R), L O D$ and $L O Q$ of the proposed method

\begin{tabular}{c|c|c|c|c|c}
\hline Element & $\begin{array}{c}\text { Linear range } \\
(\boldsymbol{\mu g} \text { kg-1 })\end{array}$ & Regression & $\mathbf{R}$ & $\begin{array}{c}\text { LOD } \\
\left(\boldsymbol{\mu g} \mathbf{~ k g}^{-1}\right)\end{array}$ & $\begin{array}{c}\mathbf{L O Q} \\
\left(\boldsymbol{\mu g} \mathbf{~ k g}^{-1}\right)\end{array}$ \\
\hline $\mathrm{Cd}$ & $0-100$ & $\mathrm{y}=0.0354 \mathrm{x}+0.0180$ & 0.9954 & 0.0132 & 0.0396 \\
$\mathrm{Cu}$ & $0-100$ & $\mathrm{y}=2.2233 \mathrm{x}+1.8768$ & 0.9997 & 0.3597 & 1.1978 \\
$\mathrm{Fe}$ & $0-100$ & $\mathrm{y}=1.1027 \mathrm{x}+1.0178$ & 0.9877 & 0.1287 & 0.4286 \\
$\mathrm{Mn}$ & $0-100$ & $\mathrm{y}=0.3952 \mathrm{x}+0.0158$ & 0.9996 & 0.1768 & 0.5887 \\
$\mathrm{Ni}$ & $0-100$ & $\mathrm{y}=0.7425 \mathrm{x}+0.2422$ & 0.9999 & 0.4377 & 1.4575 \\
$\mathrm{~Pb}$ & $0-100$ & $\mathrm{y}=0.0879 \mathrm{x}+0.1034$ & 0.9998 & 0.0832 & 0.2771 \\
$\mathrm{Zn}$ & $0-100$ & $\mathrm{y}=0.2204 \mathrm{x}+0.4320$ & 0.9997 & 1.2320 & 4.1025 \\
\hline
\end{tabular}

\section{Accuracy and precision of the method}

As a certified standard reference material (CRM 1573a), tomato leaves (National Institute of Standards and Technology, NIST, Gaithersburg, MD, USA) were used to assess the accuracy and precision of the method. The accuracy of the entire proposed method was confirmed via a standard reference material analysis. As can be seen below (Table 4), the method was validated through the analysis of the CRM, NIST 1573a, with good recoveries.

\section{Results and discussion}

The average mineral element values for the soil samples taken from the three locations are provided in Table 5. 
Table 4. Certified and determined values of metals in the CRM (NIST 1573a), tomato leaves

\begin{tabular}{c|c|c|c}
\hline Element & Certified value (mg/kg) & Found value (mg/kg) & Recovery \\
\hline $\mathrm{Cd}$ & $1.52 \pm 0.04$ & $1.50 \pm 0.02$ & 98.68 \\
$\mathrm{Cu}$ & $4.70 \pm 0.14$ & $4.68 \pm 0.08$ & 99.57 \\
$\mathrm{Fe}$ & $368 \pm 7$ & $364 \pm 1$ & 98.91 \\
$\mathrm{Mn}$ & $246 \pm 8$ & $249 \pm 2$ & 101.22 \\
$\mathrm{Ni}$ & $1.59 \pm 0.07$ & $1.62 \pm 0.03$ & 101.89 \\
$\mathrm{~Pb}$ & $30.9 \pm 0.7$ & $32.1 \pm 0.2$ & 103.89 \\
$\mathrm{Zn}$ & $1.52 \pm 0.04$ & $1.50 \pm 0.02$ & 98.68 \\
\hline
\end{tabular}

Table 5. Average mineral element values for soil samples taken from three locations (mean \pm standard deviation)

\begin{tabular}{c|c|c|c|c|c|c|c}
\hline Soil & $\begin{array}{c}\mathbf{C d} \\
(\mathbf{m g} / \mathbf{k g})\end{array}$ & $\begin{array}{c}\mathbf{C u} \\
(\mathbf{m g} / \mathbf{k g})\end{array}$ & $\begin{array}{c}\mathbf{F e} \\
(\mathbf{\%})\end{array}$ & $\begin{array}{c}\mathbf{M n} \\
\mathbf{m g} / \mathbf{k g}\end{array}$ & $\begin{array}{c}\mathbf{N i} \\
(\mathbf{m g} / \mathbf{k g})\end{array}$ & $\begin{array}{c}\mathbf{P b} \\
(\mathbf{m g} / \mathbf{k g})\end{array}$ & $\begin{array}{c}\mathbf{Z n} \\
(\mathbf{m g} / \mathbf{k g})\end{array}$ \\
\hline Cinar & $1.02 \pm 0.08$ & $34.23 \pm 2.43$ & 1.67 & $24.5 \pm 6$ & $18.37 \pm 0.89$ & $3.59 . \pm 0.46$ & $66.74 \pm 2.13$ \\
Kiziltepe & $0.94 . \pm 0.05$ & $25.78 \pm 1.65$ & 1.28 & $10.2 \pm 4$ & $15.52 \pm 0.13$ & $2.44 \pm 0.14$ & $59.14 . \pm 0.94$ \\
Siverek & $0.96 \pm 0.07$ & $29.05 \pm 1.21$ & 2.56 & $17.6 \pm 4$ & $19.24 \pm 0.25$ & $2.98 \pm 0.24$ & $67.37 \pm 3.28$ \\
\hline
\end{tabular}

As shown in Table 5, the heavy metal contents of the soil samples were determined to be $0.94-1.02 \mathrm{mg} / \mathrm{kg}$ for $\mathrm{Cd}, 25.78-34.23 \mathrm{mg} / \mathrm{kg}$ for $\mathrm{Cu}, 1.28-2.56 \%$ for $\mathrm{Fe}, 10.2-$ $24.5 \mathrm{mg} / \mathrm{kg}$ for $\mathrm{Mn}, 15.52-19.24 \mathrm{mg} / \mathrm{kg}$ for $\mathrm{Ni}, 2.44-3.59 \mathrm{mg} / \mathrm{kg}$ for $\mathrm{Pb}$ and $59.14-$ $67.37 \mathrm{mg} / \mathrm{kg}$ for $\mathrm{Zn}$. The highest values for $\mathrm{Cd}(1.02 \mathrm{mg} / \mathrm{kg}), \mathrm{Cu}(34.23 \mathrm{mg} / \mathrm{kg}), \mathrm{Mn}$ $(24.5 \mathrm{mg} / \mathrm{kg})$ and $\mathrm{Pb}(3.59 \mathrm{mg} / \mathrm{kg})$ were obtained from the Çınar location. The highest values for $\mathrm{Fe}(2.56 \%)$, Ni $(19.24 \mathrm{mg} / \mathrm{kg})$, and $\mathrm{Zn}(67.37 \mathrm{mg} / \mathrm{kg})$ were found in the Siverek location's soil. The Kiziltepe location's soil had the lowest values for all elements. The data obtained from the Fe measurements are expressed as percentages because the measured values are too high in soils. The averages of mineral element values of barley samples taken from three locations are given below (Table 6).

Table 6. Average mineral element values for barley samples taken from three locations (mean \pm standard deviation)

\begin{tabular}{c|c|c|c|c|c|c|c}
\hline Barley & $\begin{array}{c}\mathbf{C d} \\
\mathbf{m g} / \mathbf{k g}\end{array}$ & $\begin{array}{c}\mathbf{C u} \\
(\mathbf{m g} / \mathbf{k g})\end{array}$ & $\begin{array}{c}\mathbf{F e} \\
(\mathbf{m g} / \mathbf{k g})\end{array}$ & $\begin{array}{c}\mathbf{M n} \\
\mathbf{m g} / \mathbf{k g}\end{array}$ & $\begin{array}{c}\mathbf{N i} \\
(\mathbf{m g} / \mathbf{k g})\end{array}$ & $\begin{array}{c}\mathbf{P b} \\
(\mathbf{m g} / \mathbf{k g})\end{array}$ & $\begin{array}{c}\mathbf{Z n} \\
(\mathbf{m g} / \mathbf{k g})\end{array}$ \\
\hline Cinar & N.D. & $4.14 \pm 0.21$ & $67.14 \pm 1.27$ & $19.13 \pm 0.45$ & $1.71 \pm 0.15$ & $0.65 \pm 0.03$ & $18.89 \pm 0.85$ \\
Kiziltepe & N.D. & $2.57 \pm 0.14$ & $47.54 \pm 0.82$ & $9.48 \pm 0.12$ & $1.44 \pm 0.63$ & N.D. & $15.69 \pm 0.64$ \\
Siverek & N.D. & $3.42 \pm 0.50$ & $96.94 \pm 4.28$ & $15.14 \pm 0.89$ & $2.12 \pm 0.28$ & $0.54 \pm 0.05$ & $20.56 \pm 1.43$ \\
\hline
\end{tabular}

N.D.: undeterminable

As shown in Table 6, the heavy metal content of the barley samples was 2.57$4.14 \mathrm{mg} / \mathrm{kg}$ for $\mathrm{Cu}, 47.54-96.94 \mathrm{mg} / \mathrm{kg}$ for $\mathrm{Fe}, 9.48-19.13 \mathrm{mg} / \mathrm{kg}$ for $\mathrm{Mn}, 1.44-$ $2.12 \mathrm{mg} / \mathrm{kg}$ for $\mathrm{Ni}, 0.54-0.65 \mathrm{mg} / \mathrm{kg}$ for $\mathrm{Pb}$ and $15.69-20.56 \mathrm{mg} / \mathrm{kg}$ for $\mathrm{Zn}$. The amount of $\mathrm{Cd}$ in the barley plants was undeterminable (N.D.) for all locations. Lead measurements were also undeterminable (N.D.) in barley samples taken from Kiziltepe location. While the highest mean values of $\mathrm{Cu}(4.14 \mathrm{mg} / \mathrm{kg}), \mathrm{Mn}(19.13 \mathrm{mg} / \mathrm{kg})$ and $\mathrm{Pb}$ 
$(0.65 \mathrm{mg} / \mathrm{kg})$ were obtained for the Çınar location, the highest $\mathrm{Fe}(96.94 \mathrm{mg} / \mathrm{kg}), \mathrm{Ni}$ $(2.12 \mathrm{mg} / \mathrm{kg})$ and $\mathrm{Zn}(20.56 \mathrm{mg} / \mathrm{kg})$ values were obtained from the Siverek location. The Kiziltepe location had the lowest average values for all elements.

When we consider the soil and plant samples analyzed, we see that the Kizıltepe location has less $\mathrm{Cd}, \mathrm{Cu}, \mathrm{Fe}, \mathrm{Mn}, \mathrm{Ni}, \mathrm{Pb}$ and $\mathrm{Zn}$ content than the Çınar and Siverek locations. The presence of $\mathrm{Cd}$ in plant samples taken from all three locations and $\mathrm{Pb}$ in samples taken from the Kiziltepe location could not be determined.

The heavy metal limit for European countries, according to the Republic of Turkey's Ministry of Environment and Urban Soil Pollution Control Regulations limit values for heavy metals in soil and the WHO/FAO values for plants, are provided in Tables 7, 8 and 9 .

Table 7. The heavy metal limit values for European Countries, $m g / k g$ (Ozturk, 2017)

\begin{tabular}{c|c|c|c|c|c|c}
\hline Country & Quality standard & $\mathbf{C d}$ & $\mathbf{C u}$ & $\mathbf{N i}$ & $\mathbf{P b}$ & $\mathbf{Z n}$ \\
\hline Austria & Regulation on Biowaste Class A & 1 & 150 & 60 & 120 & 500 \\
Belgium & Ministry of Agriculture & 1.5 & 90 & 20 & 120 & 300 \\
Denmark & Ministry of Agriculture & 0.4 & 1000 & 30 & 120 & 4000 \\
Germany & Regulation on Biowaste Type II & 1.5 & 100 & 50 & 150 & 400 \\
Ireland & Draft & 1.5 & 100 & 50 & 150 & 350 \\
Luxembourg & Ministry of Environment & 1.5 & 100 & 50 & 150 & 400 \\
Netherland & Second Class Compost & 1 & 60 & 20 & 100 & 200 \\
Spain & Class A & 2 & 100 & 60 & 150 & 400 \\
Sweden & Quality Assurance Organization & 1 & 100 & 50 & 100 & 300 \\
England & TCA Quality Label & 1.5 & 200 & 50 & 150 & 400 \\
\hline
\end{tabular}

Table 8. The heavy metal limit values for soil in Turkey (Anonymous, 2005)

\begin{tabular}{|c|c|c|}
\hline Elements & pH 5-6 (mg/kg) & $\mathrm{pH}>6(\mathrm{mg} / \mathrm{kg})$ \\
\hline $\mathrm{Cd}$ & 1 & 3 \\
\hline $\mathrm{Cu}$ & 50 & 140 \\
\hline $\mathrm{Fe}$ & 4.5 & 4.5 \\
\hline $\mathrm{Mn}$ & 70 & 70 \\
\hline $\mathrm{Ni}$ & 30 & 75 \\
\hline $\mathrm{Pb}$ & 50 & 300 \\
\hline $\mathrm{Zn}$ & 150 & 300 \\
\hline
\end{tabular}

Table 9. The heavy metal limit values allowed by the WHO/FAO for plants (FAO/WHO, 2003)

\begin{tabular}{c|c}
\hline Elements & Limit values $(\mathbf{m g} / \mathbf{k g})$ \\
\hline $\mathrm{Cd}$ & 0.5 \\
$\mathrm{Cu}$ & 5 \\
$\mathrm{Fe}$ & 30 \\
$\mathrm{Ni}$ & 5 \\
$\mathrm{~Pb}$ & 2 \\
$\mathrm{Zn}$ & 50 \\
\hline
\end{tabular}


Comparing Tables 7, 8 and 9, we can see that the amounts of mineral elements in the plant and soil samples are generally within the permissible limits. However, the Fe in both the soil and plant samples is well above the limit values for all three locations. The Fe is twice the allowed amount in the Çinar location and three times that in the Siverek location. Excess Fe element in the soil causes excess Fe in plant samples. In all three locations, the increased $\mathrm{Fe}$, both in the soil and in the vegetation, is due to the fact that the soils and rocks of the region are rich in Fe. Özkan (2017) notes that as the distance from the highways decreases, the heavy metal levels in the plant and soil decrease in proportion to the distance. Our study suggests, no heavy metal pollution in the soil and in the plants growing in the study locations. In addition, he reports that in this soil, Fe levels are slightly above but the limit value but do not constitute a problem for plants (Ozkan, 2017). Karataş et al. (2007) investigated the concentrations of $\mathrm{Cu}, \mathrm{Cr}$, Ni and $\mathrm{Pb}$ in agricultural soils and wheat and reported that the heavy metal concentration in wheat did not reach the level of toxicity (Karatas et al., 2007).

Similar studies of mineral substances have been conducted. In a study conducted in the province of Elazı $\breve{g}, \mathrm{Cu}, \mathrm{Ni}$ and $\mathrm{Mn}$ content were reported to be 1595,489 and $1406 \mathrm{ppm}$, and these values were several times higher than those found in uncontaminated soils (Sasmaz and Yaman, 2008). In the soil of the Gediz basin, the following values have been reported: $\mathrm{Pd} 5.98-15.5 \mu \mathrm{g} / \mathrm{g}, \mathrm{Cd} 1.5-3.2 \mu \mathrm{g} / \mathrm{g}$, Ni 16.9$39.17 \mu \mathrm{g} / \mathrm{g}, \mathrm{Cu} 26.04-65.9 \mu \mathrm{g} / \mathrm{g}$, Fe 11.69-30.0 $\mu \mathrm{g} / \mathrm{g}$ and $\mathrm{Zn} 38.33-106.6 \mu \mathrm{g} / \mathrm{g}$ (Oner and Celik, 2011). Copper, $\mathrm{Zn}, \mathrm{Fe}, \mathrm{Ni}$, and $\mathrm{Mn}$ were found to be in the range of 20-50, 771443, 26 353-66 815, 20-61 and 152-1320 ppm in soil samples investigated in Niğde Province, respectively (Turan et al., 2006). In China, the heavy metal content of sediments was found to be as follows: $\mathrm{Zn} 59.85 \mathrm{mg} / \mathrm{kg}, \mathrm{Cu} 24.81 \mathrm{mg} / \mathrm{kg}, \mathrm{Pb}$ $18.31 \mathrm{mg} / \mathrm{kg}$, Ni $9.24 \mathrm{mg} / \mathrm{kg}$, Cd $0.34 \mathrm{mg} / \mathrm{kg}$ (Wu et al., 2015). In Polonia, the following values were found: $\mathrm{Cd} 1.1-2.1 \mathrm{mg} / \mathrm{kg}$, Ni 6.3-15.1 mg/kg, Cu 3.8-73.1 mg/kg, Pb 30.5$94.1 \mathrm{mg} / \mathrm{kg}, \mathrm{Zn} 43.0-189.7 \mathrm{mg} / \mathrm{kg}$, Mn 34.3-225.5 mg/kg and Fe $1853.3-21198.5 \mathrm{mg} / \mathrm{kg}$ (Mazur et al., 2013).

\section{Correlation analysis between investigated traits}

Correlation coefficients were calculated with the JMP statistical program (software of the SAS program) to identify the relationships between the investigated parameters (Kalayci, 2005). The correlation analysis of the six heavy metals is shown in Table 10. It can be seen from Table 10 that strong positive correlations were observed for $\mathrm{Fe}-\mathrm{Ni}$, $\mathrm{Fe}-\mathrm{Zn}, \mathrm{Fe}-\mathrm{Pb}, \mathrm{Ni}-\mathrm{Zn}, \mathrm{Cu}-\mathrm{Pb}, \mathrm{Cu}-\mathrm{Mn}, \mathrm{Zn}-\mathrm{Pb}$ and $\mathrm{Pb}-\mathrm{Mn}$, indicating the existence of a common origin for these metals.

Table 10. Correlation analysis of heavy metal concentrations for barley in the study area

\begin{tabular}{c|c|c|c|c|c|c}
\hline & $\mathbf{F e}$ & $\mathbf{N i}$ & $\mathbf{C u}$ & $\mathbf{Z n}$ & $\mathbf{P b}$ & $\mathbf{M n}$ \\
\hline $\mathrm{Fe}$ & 1.00 & $0.89 * *$ & 0.46 & $0.95^{* *}$ & $0.69^{*}$ & 0.50 \\
$\mathrm{Ni}$ & & 1.00 & 0.22 & $0.91^{* *}$ & 0.55 & 0.33 \\
$\mathrm{Cu}$ & & & 1.00 & 0.54 & $0.91^{* *}$ & $0.94^{* *}$ \\
$\mathrm{Zn}$ & & & & 1.00 & $0.81^{* *}$ & 0.63 \\
$\mathrm{~Pb}$ & & & & & 1.00 & $0.96^{* *}$ \\
$\mathrm{Mn}$ & & & & & & 1.00 \\
\hline
\end{tabular}

** and * correlations are significant at the 0.01 and 0.05 level, respectively 
The greatest correlation coefficient $(\mathrm{r}=0.96)$ was observed between $\mathrm{Pb}$ and $\mathrm{Mn}$, and the lowest correlation coefficient $(\mathrm{r}=0.22)$ was identified between $\mathrm{Ni}$ and $\mathrm{Cu}$. There isa very important positive relationship between $\mathrm{Fe}$ with $\mathrm{Ni}$ and $\mathrm{Zn}$, between $\mathrm{Ni}$ and $\mathrm{Zn}$, between $\mathrm{Cu}$ and both $\mathrm{Pb}$ and $\mathrm{Mn}$, between $\mathrm{Zn}$ and $\mathrm{Pb}$, between $\mathrm{Pb}$ and $\mathrm{Mn}$, and between $\mathrm{Pb}$ and $\mathrm{Fe}$.

\section{Conclusions}

In areas where industrial wastes are released into the environment without being subjected to any filtering treatment, heavy metal levels are well above the values allowed in the soil. These heavy metals accumulating in the soil have passed through underground water resources and vegetation and threatened human and animal health. As seen in this study, heavy metal pollution in rural areas is typically within prescribed limits without Fe content. This situation is desirable. However, the repetition of similar studies at specific time intervals is important for in continuing this positive situation.

\section{REFERENCES}

[1] Anonymous (2005): Official newspaper. - Regulation of Control of Soil Pollution. No: 25831: Date: 31.05.2005.

[2] Aschner, M., Erikson, K. M., Herrero Hernández, E., Tjalkens, R. (2009): Manganese and its role in Parkinson's disease: from transport to neuropathology. - Neuromolecular Med 11: 252-267.

[3] Aydin, I. (2008): Comparison of dry, wet and microwave digestion procedures for the determination of chemical elements in wool samples in Turkey using ICP-OES technique. - Microchem. J. 90: 82-87.

[4] Bernhoft, R. A. (2013): Cadmium toxicity and treatment. - The Scientific World Journal. Article ID 394652.

[5] Bora, T., Aksoy, C., Tunay, Z., Aydın, F. (2015): Determination of trace elements in illicit spice samples by using ICP-MS. - Microchemical Journal 123: 179-184.

[6] Caglairmak, N., Hepcimen, A. Z. (2010): Effect of heavy metal soil pollution on food chain and human health. - Academic Food J. 8: 31-35.

[7] Celik, K. S., Aydin, F., Duz, M. Z., Aydin, I., Erdogan, S., Akbag, O., Hamamci, C. (2014): Simultaneous determination of transition metals in hazelnuts (Corylusavellana L.) by ICP-OES. - Atomic Spectroscopy 35: 200-204.

[8] Chaney, R. L., Malik, M., Li, Y. M., Brown, S. L., Brewer, E. P., Angle, J. S., Baker, A. J. M. (1997): Phytoremediation of soil metal. - Curr Opin Biotechnol 8: 279-284.

[9] Duz, M. Z., Celik, K. S., Aydin, I., Erdogan, S., Aydin, F., Hamamci, C. (2012): Microwave digestion followed by ICP-OES for the determination of $\mathrm{Al}, \mathrm{Cd}, \mathrm{Cr}, \mathrm{Cu}, \mathrm{Fe}$, $\mathrm{Ni}, \mathrm{Pb}$, and $\mathrm{Sn}$ in maize. - Atomic Spectroscopy 33: 78-82.

[10] Ebbs, S. D., Kochian, L. V. (1998): Phytoextraction of zinc by oat (Avena sativa), barley (Hordeum vulgare), and Indian mustard (Brassica juncea). - Environmental Science \& Technology 32(6): 802-806.

[11] FAO/WHO (2003): Codex Alimentarius International Food Standards Codex Stan - 179: 2003. - Codex Alimentarius Commission, Rome.

[12] Fosmire, G. J. (1990): Zinc toxicity. - Am J ClinNutr 51: 225-227.

[13] Kahvecioglu, O., Kartal, G., Guven, A., Timur, S. (2004): Environmental effects of metals-III. - Metalurjij. 138: 64-71.

[14] Kalayci, M. (2005): Use JUMP with Examples and Anova Models for Agricultural Research. - Anatolia Agricultural Research Institute Directorate Publications No: 21. 
[15] Karatas, M., Guler, E., Dursun, S., Ozdemir, C., Argun, M. E. (2007): Determination of $\mathrm{Cu}, \mathrm{Cr}, \mathrm{Ni}$ and $\mathrm{Pb}$ concentrations in wheat and agricultural soils collected from Cengilli site of Konya main wastewater system. - S Ü Fen Ed Fak Fen Derg 29: 91-99.

[16] Kawanishi, S., Inoue, S., Oikawa, S., Yamashita, N., Toyokuni, S., Kawanishi, M., Nishino, K. (2001): Oxidative DNA damage in cultured cells and rat lungs by carcinogenic nickel compounds. - Free Radic Biol Med 31: 108-16.

[17] Mazur, Z., Radziemska, M., Maczuga, O., Makuch, A. (2013): Heavy metal concentrations in soil and moss (Pleuroziumschreberi) near railroad lines in Olsztyn (Poland). - Fresenius Environmental Bulletin 22(4): 957-963.

[18] Nagajyoti, P. C., Lee, K. D., Sreekanth, T. V. M. (2010): Heavy metals, occurrence and toxicity for plants: a review. - Environmental Chemistry Letters 8: 199-216.

[19] Okturen, A., Sonmez, F. (2006): The effect of heavy metal toxicity on plant metabolism. - Derim 23(2): 36-45.

[20] Oner, O., Celik, A. (2011): Investigation of some pollution parameters in water and sediment samples collected from the lower Gediz River Basin. - Ekoloji 20(78): 48-52.

[21] Ozkan, A. (2017): Heavy metal pollution in agricultural lands and plants around AntakyaCilvegözü highway. - Çukurova University Journal of the Faculty of Engineering and Architecture 32(3): 9-18.

[22] Ozturk, M. (2017): Compost Production from Animal Behavior and Wastes. - Ministry of Environment and Urbanization, Ankara.

[23] Sasmaz, A., Yaman, M. (2008): Determination of Different Metal Levels in Soil, Plant and Water Samples in the vicinity of Maden (Elazığ) Copper Bed. - The Scientific and Technological Research Council of Turkey, Project Number: 105 Y051.

[24] Scott, P. R., Penny, C. D., Macrae, A. I. (2011): Cattle Medicine. - Manson Publishing Ltd., London.

[25] Turan, H., Ozdemir, Z., Zorlu, S. (2006): Investigation of biogeochemical anomalies for $\mathrm{Cu}, \mathrm{Zn}, \mathrm{Fe}, \mathrm{Mn}$ and Ni in the Çiftehan (Ulukışla-Niğde) area. - İstanbul Üniv. Müh. Fak. Yerbilimleri Dergisi 19(2): 131-140.

[26] Tuzun, Y., Yakut, M. (2009): Iron metabolism and hereditary hemochromatosis. Current Gastroenterology 13: 94-100.

[27] Wu, Z., Geng, J., Huang, L. (2015): Heavy metal contamination in sediments and mangroves from Maowei Gulf, South China. - Fresenius Environmental Bulletin 24(3b): 1091-1097. 